Prive;Volume 3, Nomor 2, September 2020 http://ejurnal.unim.ac.id/index.php/prive

\title{
PENGARUH OPINI AUDIT, PERGANTIAN MANAJEMEN DAN PERTUMBUHAN PERUSAHAAN TERHADAP AUDITOR SWITCHING DENGAN FINANCIAL DISTRESS SEBAGAI VARIABEL MODERASI (Studi Empiris pada Perusahaan Sektor Keuangan yang Terdaftar di Bursa Efek Indonesia Tahun 2017-2019)
}

\author{
Nisa'ul Kaamilah' \\ Tatas Ridho Nugroho ${ }^{2}$ \\ Toto Heru Dwihandoko ${ }^{3}$ \\ ${ }^{1,2,3}$ Universitas Islam Majapahit \\ nisaulkaamilah22@gmail.com
}

\begin{abstract}
This research aims to analyze and obtain empirical evidence about the effect of audit opinion, management change and company growth on auditor switching with financial distress as a moderating variable. The population in this study were 90 financial sector companies listed on the Indonesia Stock Exchange for the 2017-2019 period. The sampling technique used purposive sampling, 42 samples were obtained for three years of observation to produce 126 units of analysis. The research data were obtained from audited financial statements, independent auditor's reports and the company's annual report downloaded from the website www.idx.co.id. The data analysis method uses descriptive statistical analysis, logistic regression analysis and Moderated Regression Analysis using SPSS version 22. The results of the study prove that simultaneous audit opinion, management change and company growth influence auditor switching. Partially the change of management and company growth has no effect on auditor switching. While audit opinion has a positive effect on auditor switching. Financial distress is able to moderate the change of management towards auditor switching, but it can't moderate the relationship between audit opinion and company growth with auditor switching at financial sector companies listed on the Indonesia Stock Exchange in 2017-2019.

Keywords: Auditor Switching, Audit Opinion, Management Change, Company Growth, Financial Distres
\end{abstract}

\footnotetext{
Abstrak

Penelitian ini bertujuan untuk menganalisis dan memperoleh bukti empiris tentang pengaruh dari opini audit, pergantian manajemen dan pertumbuhan perusahaan terhadap auditor switching dengan financial distress sebagai variabel moderasi. Populasi pada penelitian ini yaitu 90 perusahaan sektor keuangan yang terdaftar di Bursa Efek Indonesia tahun 2017-2019. Teknik pengambilan sampel menggunakan purposive sampling, diperoleh 42 sampel selama tiga tahun pengamatan sehingga menghasilkan 126 unit analisis. Data penelitian diperoleh dari laporan keuangan yang telah diaudit, laporan auditor independen dan laporan tahunan perusahaan yang diunduh dari website www.idx.co.id. Metode analisis data menggunakan analisis statistik deskriptif, analisis regresi logistik dan Moderated Regression Analysis dengan menggunakan SPSS versi 22. Hasil penelitian membuktikan bahwa secara simultan opini audit, pergantian manajemen dan pertumbuhan perusahaan berpengaruh terhadap auditor switching. Secara parsial pergantian manajemen dan pertumbuhan perusahaan tidak berpengaruh terhadap auditor switching. Sedangkan opini audit berpengaruh positif terhadap auditor switching. Financial distress mampu memoderasi pergantian manajemen terhadap auditor switching, tetapi tidak dapat memoderasi hubungan opini audit dan pertumbuhan perusahaan terhadap auditor switching pada perusahaan sektor keuangan yang terdaftar di Bursa Efek Indonesia tahun 2017-2019.

Kata Kunci: Auditor Switching, Opini Audit, Pertumbuhan Perusahaan, Pergantian Manajemen, Financial Distress
} 


\section{A. PENDAHULUAN}

Financial statement entitas perusahaan dapat dipergunakan untuk melihat baik buruknya kinerja keuangan entitas oleh pihak yang berkepentingan dari informasi yang telah tersajikan. Audit laporan keuangan ditujukan untuk memberikan pendapat atas kesesuaian dan kewajaran laporan keuangan dengan Prinsip Akuntansi Berterima Umum (PABU) (Praptika \& Rasmini, 2016). Agar dapat menjamin keandalan laporan keuangan perusahaan maka dibutuhkan auditor yang independen. Independensi auditor dapat terganggu dengan hubungan auditor-klien (auditor tenure) yang panjang, karena kapasitas penilaian kritis auditor terhadap perusahaan dapat menurun seiring berjalannya waktu (Salleh \& Jasmani, 2014). Agar dapat menjaga independensi auditor maka dibutuhkan adanya auditor switching. Auditor Switching adalah kegiatan dimana perusahaan melakukan pergantian auditor ataupun Kantor Akuntan Publik (KAP) (Maryani et al., 2017). Pergantian auditor digunakan untuk mengatasi munculnya penuruanan kualitas audit akibat dari auditor tenure atau lamanya hubungan antara auditor dengan perusahaan klien" (Cameran et al., 2009). Jatuhnya Kantor Akuntan Publik (KAP) Arthur Andersen di Amerika pada tahun 2001 yang termasuk dalam jajaran KAP Big Five didunia, mengawali diadakannya auditor switching. KAP Arthur Andersen terlibat dengan penyelewengan yang dilakukan Enron (kliennya), sehingga gagal untuk mempertahankan independensinya (Liputan6.com, 2014).

Perusahaan melakukan auditor switching dikarenakan hal tersebut bersifat mandatory (wajib) dan bisa karena pergantian auditor dengan sukarela (voluntary). Adanya keinginan dalam memperbaiki reputasi perusahaan, menginginkan auditor yang lebih kompetitif lagi sesuai dengan keadaan perusahaan dan saat lingkungan perusahaan berubah dapat menyebabkan terjadinya auditor switching secara voluntary (Karina et al., 2017). Sedangkan pergantian auditor secara mandatory terakhir diatur dalam "Peraturan Pemerintah Nomor 20 Tahun 2015 tentang Praktik Akuntan Publik, n.d. pasal 11 ayat (1) dijelaskan bahwa Kantor Akuntan Publik (KAP) tidak lagi dibatasi dalam melakukan audit atas suatu perusahaan. Pembatasan hanya berlaku bagi akuntan publik, yaitu selama 5 tahun buku berturut-turut. Perusahaan yang dimaksud dalam PP No. 20/2015 yaitu industri di sektor perbankan umum, asuransi atau reasuransi, pasar modal, dana pensiun ataupun BUMN". Kasus auditor switching yang berkaitan dengan turunnya independensi auditor saat perusahaan klien mengalami financial distress terjadi pada PT. Asuransi Jiwasraya. Perusahaan asuransi pelat merah ini telah tercium sejak tahun 2006 dalam pengawasan lembaga BAPEPAM-LK. Manajemen menyusun laporan liability yang understated dan aset investasi yang overstated, tetapi auditor memberikan unqualified opinion. Tahun 2017 KAP Pricewaterhouse Coopers memberikan opini tidak wajar dengan modifikasi, meskipun kinerja keuangan positif dan perolehan laba naik menjadi 37,63\%, hal ini menyebabkan Menteri BUMN menduga bahwa terjadi fraud dalam PT. Asuransi Jiwasraya (Katadata.co.id, 2019).

Fenomena mengenai pergantian KAP secara voluntary ataupun mandatory dilakukan oleh perusahaan di Indonesia. Hal itu dapat dilihat pada grafik di bawah ini:

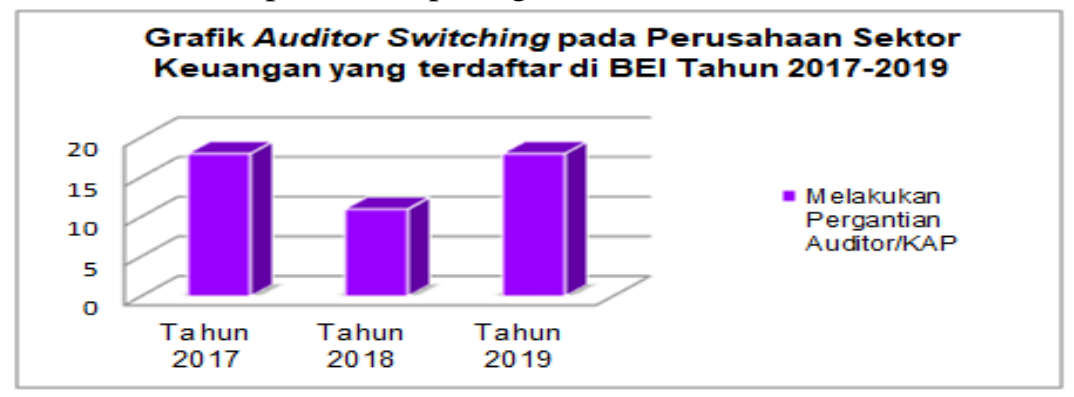

Gambar 1. Grafik Kecenderungan Terjadinya Auditor Switching

Sumber: Diolah oleh peneliti (2020)

Pada Gambar 1. menunjukkan perusahaan sektor financial yang terdaftar dalam BEI tahun 2016-2019 sebanyak 47 kali melakukan auditor switching. Pada tahun 2017 terdapat 18 perusahaan yang melakukan auditor switching. Tahun 2018 terjadi penurunan sehingga hanya ada 11 perusahaan yang melakukan auditor switching. Tahun 2019 mengalami peningkatan kembali sebanyak 18 perusahaan yang melakukan auditor switching. Terdapat dua faktor yang menyebabkan menurunnya maupun meningkatnya auditor switching, di antaranya adalah faktor yang terkait auditor (auditor related factor), yang terdiri dari: opini audit, fee audit dan kualitas 
audit serta faktor yang berasal dari klien (client related factor) yang terdiri dari: ukuran perusahaan, pergantian manajemen dan financial distress (Khasharmeh, 2015).

Salah satu faktor yang dapat mempengaruhi terjadinya auditor switching adalah opini audit (Carcello \& Neal, 2003; Hudaib \& Cook, 2005; Calderon \& Ofobike, 2008; Svanberg \& Ohman, 2015). Opini audit merupakan pernyataan opini atau pendapat dari auditor, setelah auditor melakukan pemeriksaan atas kewajaran suatu laporan keuangan perusahaan klien. Seorang auditor kemungkinan diberhentikan setelah menyajikan laporan audit yang tidak sesuai dengan keinginan manajemen yang menginginkan unqualified opinion (Holowczak et al., 2019). Opini audit dapat menjadi pertimbangan perusahaan dalam melakukan auditor switching. Dampak opini audit ini berpengaruh signifkan terhadap kelangsungan hidup perusahaan. Jika auditor tidak dapat memberikan opini wajar tanpa pengecualian, perusahaan akan melakukan auditor switching yang mungkin dapat memberikan opini sesuai dengan yang diharapkan perusahaan (Yusriwarti, 2019). Hasil penelitian yang dilakukan oleh Alexandra et al., (2016), Putra \& Suryanawa (2016) menunjukkan bahwa opini audit berpengaruh terhadap auditor switching. Sedangkan pada penelitian yang dilakukan oleh (Budisantoso et al., 2017) dan (Safriliana \& Muawanah, 2019) menunjukkan bahwa opini audit berpengaruh negatif terhadap auditor switching.

Faktor lainnya yang dapat menyebabkan perusahaan melakukan pergantian auditor secara sukarela dan tidak mentaati peraturan yang berlaku, faktor tersebut dapat berasal dari perusahaan maupun auditor itu sendiri, yaitu pergantian manajemen. Pergantian manajemen merupakan pergantian direksi atau Chief Executive Officer (CEO) yang dihasilkan dari rapat umum pemegang saham di dalam perusahaan atau karena direksi ingin berhenti sendiri. Dengan adanya pergantian manajemen maka akan ada perubahan kebijakan perusahaan yang baru dalam bidang akuntansi, keuangan dan pemilihan KAP (Sya'diah \& Riduwan, 2015). Hasil penelitian yang dilakukan oleh Karina et al., (2017) dan Dermawan, (2019) menunjukkan bahwa pergantian manajemen tidak berpengaruh terhadap auditor switching. Sedangkan pada penelitian yang dilakukan oleh Saputra, (2017) dan Manto \& Lesmana Wanda, (2018) menunjukkan hasil yang sama bahwa pergantian manajemen berpengaruh positif terhadap auditor switching.

Faktor lain yang dapat mempengaruhi terjadinya auditor switching dalam perusahaan adalah pertumbuhan perusahaan. Tingkat pertumbuhan perusahaan merupakan kemampuan perusahaan dalam mempertahankan kualitas baik industrinya maupun kegiatan ekonominya secara keseluruhan (Weston \& Copeland, 1997). Ketika pertumbuhan perusahaan tinggi, perusahaan akan cenderung mempertahankan KAP dari pada saat tingkat pertumbuhan perusahaan negatif atau rendah. Hal ini disebabkan oleh bisnis yang terus bertumbuh, permintaan untuk independensi yang lebih tinggi dan perusahaan memilih KAP yang berkualitas untuk menghindari konflik keagenan sehingga dapat memberikan layanan jasa non audit yang dibutuhkan untuk meningkatkan perluasan perusahaan (Primbardi, 2014). Hasil penelitian yang dilakukan oleh Karina et al., (2017) menunjukkan bahwa pertumbuhan perusahaan berpengaruh terhadap auditor switching. Sedangkan pada penelitian yang dilakukan oleh (Syofyan, 2019) serta (Walidi, 2019) menunjukkan bahwa pertumbuhan perusahaan tidak berpengaruh terhadap auditor switching.

Penelitian ini berfokus kepada pergantian auditor eksternal/KAP secara voluntary. Berdasarkan kecenderungan peningkatan dan penurunan auditor switching pada perusahaan sektor keuangan dan research GAP dari hasil penelitian sebelumnya yang terdapat hasil yang tidak konsisten dan terdapat pertentangan mengenai faktor-faktor yang mempengaruhi auditor switching maka hal tersebut mendorong peneliti untuk menguji pengaruh opini audit, pergantian manajemen dan pertumbuhan perusahaan terhadap auditor switching dengan financial distress sebagai variabel moderasi. Financial distress merupakan suatu kondisi perusahaan yang mengalami kesulitan dalam keuangannya. Financial distress diproksikan dengan rasio Debt to Equity Ratio (DER), yang menyatakan semakin tinggi rasio DER menunjukkan tingginya tingkat hutang sehingga berdampak semakin tinggi beban perusahaan kepada pihak kreditur. Perusahaan mendekati kebangkrutan akan menyebabkan tingginya perusahaan melakukan auditor switching, karena perusahaan akan lebih mempunyai kepercayaan diri jika diaudit oleh auditor yang mempunyai kualitas yang lebih tinggi dari auditor sebelumnya dan hal tersebut akan menumbuhkan kepercayaan bagi pihak shareholders (Yusriwarti, 2019). Pada penelitian yang dilakukan oleh Pradana Pinto, (2016) menunjukkan bahwa financial distress berpengaruh positif terhadap auditor switching. Sedangkan pada penelitian yang dilakukan oleh Putra \& Suryanawa (2016) menunjukkan financial distress tidak 
mampu memoderasi pengaruh reputasi KAP dan opini audit pada auditor switching serta penelitian yang dilakukan oleh (Safriliana \& Muawanah, 2019) financial distress tidak mempengaruhi auditor switching.

Agency theory merupakan sebuah konsep hubungan antara pemegang saham selaku principal dengan manajer perusahaan selaku agent, yang mengakibatkan asimetri informasi antara kedua belah pihak. Berdasarkan teori agensi (agency theory), konflik akibat perbedaan kepentingan dan simetri informasi yang terjadi diantara principal dengan agen membutuhkan pihak yang menjadi penengah bagi kedua belah pihak yaitu auditor independen. Apabila pihak manajemen (agen) tidak sepakat atau sejalan dengan praktik audit yang diterapkan oleh auditor, mereka akan berfikir untuk untuk melakukan pergantian auditor karena mereka menganggap bahwa hal tersebut akan menghambat tujuan mereka (Jensen \& Meckling, 1976)

Teori sinyal atau signaling theory yang dikembangkan oleh Ross tahun 1977 yang menyatakan bahwa pihak eksekutif perusahaan memiliki informasi lebih baik mengenai perusahaannya akan terdorong untuk menyampaikan informasi tersebut kepada calon investor agar harga saham perusahaannya meningkat serta agar investor tertarik untuk menanamkan saham pada perusahaan. Pemberian sinyal juga ditujuakan untuk mengurangi asymetric information antara manajemen dengan investor. Teori sinyal menyatakan bahwa klien melakukan auditor switching ketika mereka ingin menyampaikan sinyal kepada publik mengenai kualitas dan keandalan laporan keuangan mereka dan hal ini juga dilakukan melalui jenis auditor yang terlibat (Bagherpour et al., 2010).

Berdasarkan latar belakang di atas maka penulis tertarik untuk mengambil judul "Pengaruh Opini Audit, Pergantian Manajemen dan Pertumbuhan Perusahaan terhadap Auditor Switching dengan Financial Distress sebagai Variabel Moderasi (Studi Empiris pada Perusahaan Sektor Keuangan yang Terdaftar di Bursa Efek Indonesia Periode Tahun 20172019)".

\section{B. TELAAH LITERATUR DAN PENGEMBANGAN HIPOTESIS}

Perusahaan sebagai klien yang mengganti auditornya tanpa alasan yang jelas, bisa disebabkan oleh ketidakpuasan klien terhadap jasa yang diberikan oleh auditor yang lama. Seringkali terjadinya pergantian auditor terjadi karena adanya perselisihan antara klien dan auditornya mengenai penyajian laporan keuangan dan pendapat opini dari auditor (Mulyadi, 2014). Manajemen tentunya menginginkan unqualified opinion (wajar tanpa pengecualian) yang dapat menarik para investor maka dengan hal itu manajemen dapat memutuskan untuk mengganti auditornya jika tidak sejalan dengan keinginan manajemen (Faradila et al., 2016). Manajemen sebagai manusia akan bertindak individual dengan mengutamakan kepentingannya sendiri (Eisenhardt, 1989). Manajemen yang mementingkan dirinya sendiri merasa berhak untuk untuk melakukan pergantian auditor jika opini yang diberikan auditor tidak sesuai dengan keinginan manajemen. Seorang auditor yang dituntut untuk melakukan kecurangan dalam pemberian opini yang tidak sesuai dengan penliaiannya akan cenderung memutuskan kontrak audit dengan perusahaan sehingga hal ini juga dapat mengakibatkan terjadinya auditor switching. Penelitian yang dilakukan oleh Dermawan (2019), Saputra (2017), serta Putra \& Suryanawa, (2016) memperoleh hasil bahwa opini audit berpengaruh signifikan terhadap auditor switching.

$\mathrm{H}_{1}$ : Opini audit berpengaruh positif terhadap auditor switching.

Pergantian manajemen diartikan sebagai pergantian direksi perusahaan atau Chief Executive Officier (CEO) yang terutama disebabkan oleh Rapat Umum Pemegang Saham (RUPS) maupun adanya kemauan sendiri dari direksi untuk berhenti (Saputra, 2017). Dengan adanya manajemen yang baru terdapat kemungkinan besar untuk melakukan perubahan di bidang akuntansi perusahaan seperti halnya pemilihan auditor dan Kantor Akuntan Publik (KAP) yang baru. Manajemen cenderung memilih auditor yang sejalan dengan pilihan dan sesuai dengan penerapan kebijakan akuntansi mereka yang baru (Chadegani et al., 2011). Manajemen membutuhkan jasa auditor untuk mengaduit laporan keuangan perusahaan sehingga laporan tersebut menjadi relevan dan andal. Akan tetapi dengan adanya manajemen yang baru tentunya diikuti oleh kebijakan perusahaan yang baru. Kebijakan perusahaan yang baru akan memicu terjadinya pergantian auditor (auditor switching) dalam perusahaan. Hasil penelitian Saputra (2017) dan Saputri, (2018) menunjukkan bahwa pergantian manajemen berpengaruh positif terhadap auditor switching. 
$\mathrm{H}_{2}$ : pergantian manajemen berpengaruh terhadap auditor switching.

Pertumbuhan perusahaan mencerminkan dan merupakan tolak ukur bagi keberhasilan suatu perusahaan (Hery, 2016). Tingkat pertumbuhan perusahaan menjadi salah satu hal yang perlu dipertimbangkan bagi investor untuk membuat keputusan terhadap investasinya (Maryani et al., 2017). Pertumbuhan perusahaan dapat dinilai dari tingkat penjualan dan laba bersih yang diperoleh, karena semakin tinggi penjualan suatu perusahaan maka laba bersih yang akan diperoleh juga semakin besar (Rosita, 2019). Ketika perusahaan sedang mengalami pertumbuhan maka independensi harus lebih ditingkatkan. Perusahaan yang terus tumbuh akan cenderung untuk melakukan pergantian auditor karena mereka membutuhkan auditor yang mampu mengiringi perubahan yang terjadi akibat pertumbuhan perusahaan. Pemilihan auditor yang berkualitas dinilai sangat penting, hal ini dilakukan manajemen agar perusahaan memperoleh kualitas audit yang lebih baik dan dapat menghasilkan informasi yang akurat dan dapat dipercaya (Rosita, 2019). Dalam penelitian yang dilakukan oleh Faradila et al., (2016) dan Nazri et al., (2012) menunjukkan hasil bahwa pertumbuhan perusahaan berpengaruh secara signifikan terhadap auditor switching.

$\mathrm{H}_{3}$ : Pertumbuhan perusahaan berpengaruh positif terhadap auditor switching.

Opini yang diberikan seorang auditor merupakan pendapat dari akuntan publik atas baik buruknya kinerja dari seorang manajer perusahaan. Perusahaan yang mendapatkan selain opini wajar tanpa pengecualian dengan pertumbuhan perusahaan yang cenderung menurun akan membuat pemegang saham menilai bahwa kinerja dari seorang manajer buruk, yang akan menimbulkan pergantian manajer melalui Rapat Umum Pemegang Saham (RUPS). Opini yang diberikan auditor sebelumnya dapat mempengaruhi nilai saham yang berpengaruh terhadap pertumbuhan perusahaan. Hal tersebut menyebabkan terjadinya auditor switching, karena manajer atau CEO yang baru untuk memilih akuntan publik maupun KAP yang dapat diajak bekerja sama dan selaras dengan kebijakan serta pelaporan akuntansinya. Penelitian yang dilakukan oelh (Karina et al., (2017) menunjukkan bahwa opini audit dan pertumbuhan perusahaan berpengaruh positif terhadap auditor switching.

$\mathrm{H}_{4}$ : Opini audit, pergantian manajemen dan pertumbuhan perusahaan berpengaruh terhadap auditor switching.

Kondisi perusahaan yang tidak pasti dan terindikasi adanya potensi financial distress membuat manajemen perusahaan cenderung akan mengganti auditornya dalam hal opinion shopping ataupun mengganti auditor untuk menekan fee audit (Yudha et al., 2017). Jadi perusahaan yang sedang mengalami kesulitan keuangan atau financial distress akan membuat manajemen untuk mengganti auditor, dengan tujuan agar dapat memperoleh opini audit yang sesuai dengan keinginan manajemen dan menekan fee audit sehingga keuangan perusahaan dapat bangkit dari financial distress. Penelitian yang dilakukan oleh Astria \& Wenny, (2018) menunjukkan bahwa financial distress mampu memoderasi opini audit terhadap auditor switching. Dalam hal ini jika perusahaan sedang mengalami kondisi financial distress dan auditor memberikan qualified opinion (wajar dengan pengecualian) maka memperkuat interaksi tersebut.

$\mathrm{H}_{5}$ : Financial distress memperkuat pengaruh opini audit terhadap auditor switching.

Perusahaan mengalami kesulitan keuangan dapat menyebabkan pemberhentian tenaga kerja. Tanda-tanda perusahaan yang mengalami kesulitan keuangan dapat dilihat dari laporan keuangannya (Hudaib \& Cooke, 2005). Pergantian manajemen baru biasanya akan mengakibatakan perubahan kebijakan dalam perusahaan. Hal ini akan mengakibatkan adanya pergantian auditor karena manajemen baru menginginkan Kantor Akuntan Publik (KAP) yang sesuai dengan kebijakan pelaporan akuntansinya (Ulya, 2019). Manajemen yang baru berharap bahwa auditor/KAP baru dianggap lebih bisa diajak bekerja sama dan lebih bisa memberikan opini seperti yang diharapkan oleh manajemen, disertai dengan adanya preferensi tersendiri tentang auditor yang akan digunakannya, pergantian auditor/KAP dapat terjadi dalam perusahaan (Aprillia, 2013). Dengan adanya manajemen yang baru maka kebijakan-kebijakan di dalam perushaan juga akan berubah, seperti kebijakan dalam akuntansi dan melakukan pergantian auditor yang sesuai dengan kebijakan manajemen yang baru. Hasil penelitian yang dilakukan oleh Rosita, (2019) menunjukkan bahwa financial distress mampu berpengaruh dan mampu memoderasi (memperkuat) hubungan antara pergantian manajemen terhadap pergantian auditor (auditor switching).

$\mathrm{H}_{6}$ : Financial distress memperkuat pengaruh pergantian manajemen terhadap auditor switching. 
Semakin tinggi tingkat pertumbuhan perusahaan maka kecenderungan untuk melakukan pergantian auditor juga tinggi, karena perusahaan yang sedang tumbuh akan memilih kantor akuntan publik yang dapat meningkatkan kualitas perusahaan. Namun, ketika perusahaan mengalami pertumbuhan yang negatif atau rendah dan perusahaan mengalami kondisi kesulitan keuangan (financial distress) maka perusahaan akan cenderung untuk mempertahankan auditornya dengan tujuan untuk menjaga kepercayaan dari para pemakai laporan keuangan (Abdul Nasser et al., 2006). Penelitian yang dilakukan oleh Rosita, (2019) menunjukkan bahwa financial distress mampu berpengaruh namun tidak mampu memoderasi hubungan pertumbuhan perusahaan terhadap pergantian auditor (auditor switching) karena perusahaan yang sedang mengalami financial distress akan cenderung mempertahankan auditornya dengan tujuan menjaga kepercayaan dari pemakai laporan keuangan dan untuk mempertimbangkan fee auditnya.

$\mathrm{H}_{7}$ : Financial distress memperlemah pengaruh pertumbuhan perusahaan terhadap auditor switching.

\section{METODE PENELITIAN}

1. Sumber, Jenis Data, Waktu dan Tempat Penelitian.

Data sekunder berupa financial statement tahunan yang telah dipublikasi di Bursa Efek Indonesia (BEI) tahun 2017-2019 menjadi sumber data dalam penelitian. Jenis data yang dipergunakan merupakan data kuantitatif, dimana data yang diperlukan berupa angka dan diolah menggunakan rumus. Data kauntitatif pada penelitian diambil maupun diunduh melalui website BEI yaitu www.idx.co.id. Penelitian ini termasuk penelitian asosiatif kausal. Penelitian ini juga menggunakan metode analisis non parametrik, karena sebagian besar data diukur menggunakan skala nominal. Pelaksanaan penelitian ini dimulai pada bulan Maret -Juni 2020.

\section{Populasi dan Sampel}

Populasi pada penelitian ini yaitu seluruh perusahaan sektor keuangan yang go public di BEI tahun 2017-2019. Teknik purposive sampling digunakan untuk mengambil sampel penelitian, dimana metode pengumpulannya didasarkan dengan kriteria tertentu yang bertujuan agar memperoleh sampel yang sesuai kreiteria yang telah ditetapkan sebelumnya (Jogiyanto, 2010). Berikut ini kriteria yang dipergunakan untuk pengambilan sampel:

\section{Tabel 1. Sampel Penelitian}

\begin{tabular}{clc}
\hline No & \multicolumn{1}{c}{ Kriteria } & Jumlah \\
\hline 1. & $\begin{array}{l}\text { Perusahaan sektor keuangan yang sudah go public dan aktif di Bursa Efek Indonesia selama periode } \\
2017-2019 .\end{array}$ & 90 \\
\hline 2. & $\begin{array}{l}\text { Perusahaan sektor keuangan yang mempublikasikan laporan keuangan secara lengkap dan yang telah } \\
\text { diaudit dan berkaitan dengan keseluruhan variabel yang dibutuhkan dalam penelitian selama periode } \\
\text { 2017-2019. }\end{array}$ & 86 \\
\hline 3. & $\begin{array}{l}\text { Perusahaan sektor keuangan yang mengalami delisting dari Bursa Efek Indonesia selama periode } \\
\text { 2017-2019. }\end{array}$ & $(5)$ \\
\hline 4. & $\begin{array}{l}\text { Perusahaan sektor keuangan yang melakukan pergantian auditor eksternal/ KAP pada periode 2017- } \\
\text { 2019. }\end{array}$ & 42 \\
\hline Jumlah Sampel Penelitian & $\mathbf{4 2}$ \\
\hline Tahun Pengamatan & $\mathbf{3}$ \\
\hline Jumlah pengamatan yang dijadikan sampel selama periode penelitian & $\mathbf{1 2 6}$ \\
\hline
\end{tabular}

Sumber: Diolah oleh peneliti (2020).

\section{Variabel dan Definisi Operasional}

Berikut merupakan variabel yang dipergunakan pada penelitian yang dapat dilihat pada tabel 2 di bawah ini:

Tabel 2. Definisi operasional Variabel

\begin{tabular}{|c|c|c|c|c|}
\hline No & Variabel & Definisi & Indikator & Skala \\
\hline 1. & $\begin{array}{c}\text { Variabel } \\
\text { Independen: Opini } \\
\text { Audit }\left(\mathrm{X}_{1}\right)\end{array}$ & $\begin{array}{l}\text { Opini audit adalah pernyataan auditor } \\
\text { eksternal berdasarkan kewajaran financial } \\
\text { statement atas hasil audit. Kewajaran yang } \\
\text { dimaksud adalah materialitas salah saji } \\
\text { dalam financial statement perusahaan } \\
\text { (Safriliana \& Muawanah, 2019). }\end{array}$ & $\begin{array}{l}\text { Perusahaan yang mendapatkan opini } \\
\text { unqualified opinion (WTP) akan } \\
\text { diberi nilai } 0 \text { dan perusahaan yang } \\
\text { mendapatkan opini selain WTP diberi } \\
\text { nilai } 1 \text {. }\end{array}$ & Nominal \\
\hline 2. & Variabel & Pergantian manajemen diartikan sebagai & Perusahaan yang melakukan & Nominal \\
\hline
\end{tabular}




\begin{tabular}{|c|c|c|c|c|}
\hline & $\begin{array}{l}\text { Independen: } \\
\text { Pergantian } \\
\text { Manajemen }\left(\mathrm{X}_{2}\right)\end{array}$ & $\begin{array}{l}\text { pergantian direktur utama /CEO yang } \\
\text { disebabkan Rapat Umum Pemegang } \\
\text { Saham maupun kemauan direktur utama } \\
\text { untuk berhenti (Saputra, 2017). }\end{array}$ & $\begin{array}{l}\text { pergantian manajemen diberi nilai } 1 \\
\text { dan perusahaan yang tidak melakukan } \\
\text { pergantian manajemen diberi nilai } 0 .\end{array}$ & \\
\hline 3. & $\begin{array}{c}\text { Variabel } \\
\text { Independen: } \\
\text { Pertumbuhan } \\
\text { Perusahaan }\left(\mathrm{X}_{3}\right)\end{array}$ & $\begin{array}{l}\text { Pertumbuhan perusahaan merupakan } \\
\text { kemampuan perusahaan dalam } \\
\text { mempertahankan kualitas baik } \\
\text { industrinya maupun kegiatan } \\
\text { ekonominya secara keseluruhan } \\
\text { (Weston \& Copeland, 1997). }\end{array}$ & $\begin{array}{l}\text { Growth }=\frac{\text { Total Aset }(t)-\text { Total Aset }(t-1)}{\text { Total Aset }(t-1)} \times 100 \% \\
\text { Keterangan: } \\
\text { Total Aset }(\mathrm{t})=\text { Total aset periode } \\
\text { sekarang } \\
\text { Total Aset }(\mathrm{t}-1)=\text { Total asset periode } \\
\text { sebelumnya. }\end{array}$ & Rasio \\
\hline 4. & $\begin{array}{c}\text { Variabel } \\
\text { Dependen: } \\
\text { Auditor Switching } \\
(\mathrm{Y})\end{array}$ & $\begin{array}{l}\text { Auditor Switching adalah kegiatan dimana } \\
\text { perusahaan melakukan pergantian auditor } \\
\text { ataupun Kantor Akuntan Publik (Maryani } \\
\text { et al., 2017). }\end{array}$ & $\begin{array}{l}\text { Perusahaan yang mengganti auditor } \\
\text { akan diberikan nilai } 1 \text { dan jika } \\
\text { perusahaan tidak mengganti auditor } \\
\text { diberikan nilai } 0 .\end{array}$ & Nominal \\
\hline 5. & $\begin{array}{l}\text { Variabel Moderasi: } \\
\text { Financial Distress } \\
\text { (Z) }\end{array}$ & $\begin{array}{l}\text { Financial distress adalah kondisi dimana } \\
\text { perusahaan sedang mengalami kesulitan } \\
\text { keuangan (Putra \& Suryanawa, 2016). }\end{array}$ & $D E R=\frac{\text { Total Hutang }}{\text { Total Ekuitas }} \times 100 \%$ & Rasio \\
\hline
\end{tabular}

\section{Teknik Analisis Data}

Teknik analisis data yang dibutuhkan pada penelitian ini yakni:

\section{a. Uji Statistik Deskriptif}

Uji statistik deskriptif digunakan untuk menggambarkan ataupun mendeskrisikan data yang dapat dilihat dari nilai rata-rata (mean), nilai minimum-maksimum dan standar deviasi (standart deviation) (Ghozali, 2013).

\section{b. Uji Frekuensi (Frequency)}

Uji frekuensi adalah salah satu bentuk ukuran pada statistik deskriptif yang memerlihatkan besar kecilnya nilai distribusi data penelitian yang mempunyai kategori sama dan dinyatakan dalam ukuran absolute atau proporsi (\%).

\section{c. Analisis Regresi Logistik}

Logistic regression dipergunakan untuk menguji apakah tingkat signifikansi (probabilitas) dalam variabel dependen bisa diprediksi oleh variabel independen. Dalam Logistic regression, variabel dependen bersifat non-metrik (memiliki kategori) dan berupa data kualitatif sehingga pengukurannya menggunakan variabel dummy (Ghozali, 2013). Hipotesis penelitian diuji dengan menggunakan regresi logistik dengan analisis berikut: (1) Uji keseluruhan model (Overall model fit), (2) Uji koefisien determinasi (Nagelkerke $R$ Square), (3) Uji kelayakan model regresi logistik (Hosmer and Lomeshow's Goodness of Fit Test), (4) Matriks klasifikasi dan (5) Uji multikolinearitas.

\section{Uji Hipotesis}

Uji hiotesis yang dipergunakan yaitu: (1) Uji signifikasi parsial (uji wald statistic), uji wald statistic ditujukan guna menguji signifikansi pengaruh secara parsial. (2) Uji signifikasi simultan (Omnibus Test), digunakan untuk menguji logistic regression yang melibatkan variabel independen signifikan secara simultan lebih baik dibandingkan dengan model sebelumnya (model sederhana). (3) Uji variabel moderasi menggunakan Moderated Regression Analysis (MRA)dimana dalam persamaan regresinya terdapat interaksi atau perkalian antara dua maupun lebih variabel bebas. Uji interaksi (MRA) dipergunakan untuk menguji variabel moderating dalam memoderasi hubungan antara variabel bebas terhadap variabel terikat dengan melihat interaksi variabel independen dengan variabel moderating. Pengambilan keputusan pada uji hipotesis dengan regresi logistik dilaksanakan dengan melihat perbandingan nilai signifikansi (probabilitas) dengan tingkat kealpahan 0,05 (5\%). Apabila tingkat signifikan $(<0,05)$ maka $\mathrm{H}_{\mathrm{a}}$ diterima. Sebaliknya jika tingkat signifikan $(>0,05)$ maka $\mathrm{H}_{0}$ ditolak (Ghozali, 2013).

\section{HASIL DAN PEMBAHASAN}

Sesuai dengan hasil olah data melalui program aplikasi SPSS Versi-22 maka didapatkan hasil sebagai berikut:

\section{Hasil Analisis Statistik Deskritif}


Untuk mendeskripsikan dan menggambarkan data variabel Opini Audit $\left(\mathrm{X}_{1}\right)$, Pergantian Manajemen $\left(\mathrm{X}_{2}\right)$, Pertumbuhan Perusahaan $\left(\mathrm{X}_{3}\right)$, Auditor Switching $(\mathrm{Y})$ dan Financial Distress $(\mathrm{Z})$ dibutuhkan analisis statistik deskriptif yang telah disajikan pada tabel 3.

Tabel 3. Hasil Analisis Statistik Deskriptif

\begin{tabular}{lccccc}
\hline \multicolumn{7}{c}{ Descriptive Statistics } \\
\hline Auditor Switching & $\mathrm{N}$ & Minimum & Maximum & Mean & Std. Deviation \\
\hline Opini Audit & 126 & 0 & 1 & .37 & .486 \\
\hline Pergantian Manajemen & 126 & 0 & 1 & .46 & .500 \\
\hline Pertumbuhan Perusahaan & 126 & 0 & 1 & .25 & .432 \\
\hline Financial Distress & 126 & -23.00 & 578.84 & 16.6306 & 57.03624 \\
\hline \multicolumn{1}{c}{ Valid N (listwise) } & 126 & .54 & 1549.83 & 387.3734 & 305.80317 \\
\hline
\end{tabular}

Sumber: Data diolah SPSS (2020)

Hasil analisis statistik deskriptif tabel 3. menunjukkan jumlah data yang digunakan sebanyak 126 data dan semuanya valid. Auditor switching (Y) mempunyai nilai min 0 dan nilai maks 1 , ratarata dan std. Deviasi sebesar 0,37 dan 0,486 . Opini audit $\left(\mathrm{X}_{1}\right)$ mempunyai nilai min 0 dan nilai maks 1, rata-rata dan std. deviasi sebesar 0,46 dan 0,500. Pergantian manajemen $\left(\mathrm{X}_{2}\right)$ mempunyai nilai min 0 dan nilai maks 1 , rata-rata dan std. Deviasi sebesar 0,25 dan 0,432. Hasil statistik deskriptif pada variabel $\mathrm{Y}, \mathrm{X}_{1}$ dan $\mathrm{X}_{2}$ tidak daat digunakan sebagai alat analisis data karena menggunakan skala nominal. Pertumbuhan perusahaan $\left(X_{3}\right)$ mempunyai nilai min $-23,00$ dan nilai maks 578,0364 rata-rata dan std. deviasi sebesar 16,6306 dan 57,0364. Financial distress (Z) mempunyai nilai min 0,54 dan nilai maks 1549,83 rata-rata dan std. deviasi sebesar 387,3734 dan 305,80317.

2. Uji Frekuensi (Frequency)

a. Uji Frekuensi Variabel Auditor Switching

Tabel 4. Uji Statistik Frekuensi Variabel Auditor Switching

\begin{tabular}{|c|c|c|c|c|c|}
\hline \multicolumn{6}{|c|}{ Auditor Switching } \\
\hline & & Frequency & Percent & Valid Percent & Cumulative Percent \\
\hline \multirow[t]{3}{*}{ Valid } & Tidak Mengganti Auditor/KAP & 79 & 62.7 & 62.7 & 62.7 \\
\hline & Mengganti Auditor/KAP & 47 & 37.3 & 37.3 & 100.0 \\
\hline & Total & 126 & 100.0 & 100.0 & \\
\hline
\end{tabular}

Sumber: Output SPSS, diolah Juni 2020

Sesuai dengan hasil tabel 4. dilihat bahwa dari tahun 2017-2019 perusahaan yang tidak mengganti auditor/KAP sejumlah 79 perusahaan dengan persentase $62,7 \%$, sedangkan perusahaan yang melakukan pergantian auditor/KAP hanya ada 47 dengan persentase sebesar 37,3\%.

b. Uji Frekuensi Variabel Opini Audit

Tabel 5. Uji Statistik Frekuensi Variabel Opini Audit

\begin{tabular}{cccccc}
\hline \multicolumn{5}{c}{ Opini Audit } \\
\hline \multirow{2}{*}{ Valid } & Frequency & Percent & Valid Percent & Cumulative Percent \\
\hline \multirow{2}{*}{ Opini WTP } & 68 & 54.0 & 54.0 & 54.0 \\
\cline { 2 - 6 } & Selain opini WTP & 58 & 46.0 & 46.0 & 100.0 \\
\cline { 2 - 6 } & Total & 126 & 100.0 & 100.0 & \\
\hline
\end{tabular}

Sumber: Output SPSS Versi 22, diolah Juni 2020

Hasil uji statistik frekuensi tabel 5. menunjukkan dari tahun 2017-2019 sebesar 68 mendapatkan opini Wajar Tanpa Pengecualian (WTP) dengan persentase 54\% dan sisanya 58 perusahaan dengan nilai $46 \%$ perusahaan menerima opini selain WTP.

c. Uji Frekuensi Variabel Pergantian Manajemen

Tabel 6. Uji Statistik Frekuensi Variabel Pergantian Manajemen

\begin{tabular}{|c|c|c|c|c|c|}
\hline \multicolumn{6}{|c|}{ Pergantian Manajemen } \\
\hline & & Frequency & Percent & Valid Percent & Cumulative Percent \\
\hline \multirow[t]{3}{*}{ Valid } & $\begin{array}{l}\text { Tidak Mengganti } \\
\text { manajemen/CEO }\end{array}$ & 95 & 75.4 & 75.4 & 75.4 \\
\hline & Mengganti manajemen/CEO & 31 & 24.6 & 24.6 & 100.0 \\
\hline & Total & 126 & 100.0 & 100.0 & \\
\hline
\end{tabular}

Sumber: Output SPSS, diolah Juni 2020

Sesuai dengan tabel 6. dari tahun 2017-2019 terdapat 95 perusahahaan tidak melakukan pergantian manajemen/CEO dengan persentase sebesar $75,4 \%$ dan sisanya 31 perusahaan yang melakukan pergantian manajemen/CEO dengan nilai persentase sebesar $24,6 \%$. 
3. Analisis Regresi Logistik (Logistic Regression)

a. Uji Keseluruhan Model (Overall Model Fit)

Tabel 7. Likelihood Block 0

\begin{tabular}{llrr}
\hline & \multicolumn{3}{c}{ Iteration Historya,b,c } \\
\hline Iteration & & -2 Log likelihood & \multicolumn{1}{c}{ Coefficients } \\
\cline { 4 - 4 } & & & \multicolumn{1}{c}{ Constant } \\
\hline Step 0 & 1 & 166.460 & -.508 \\
\cline { 2 - 4 } & 2 & 166.456 & -.519 \\
\cline { 2 - 4 } & 3 & 166.456 & -.519 \\
\hline
\end{tabular}

Sumber: Output SPSS Versi 22, data diolah Juni 2020

Tabel 8. Likelihood Block 1

\begin{tabular}{|c|c|c|c|c|c|c|}
\hline \multicolumn{7}{|c|}{ Iteration History ${ }^{\mathrm{a}, \mathrm{b}, \mathrm{c}, \mathrm{d}}$} \\
\hline \multirow{2}{*}{\multicolumn{2}{|c|}{ Iteration }} & \multirow{2}{*}{$\begin{array}{c}-2 \text { Log } \\
\text { likelihood }\end{array}$} & \multicolumn{4}{|c|}{ Coefficients } \\
\hline & & & Constant & X1_OPA & X2_PMJ & X3_GROWTH \\
\hline \multirow[t]{4}{*}{ Step 1} & 1 & 136.759 & -1.428 & 1.779 & .213 & .003 \\
\hline & 2 & 135.738 & -1.729 & 2.052 & .277 & .005 \\
\hline & 3 & 135.722 & -1.761 & 2.076 & .283 & .005 \\
\hline & 4 & 135.722 & -1.762 & 2.077 & .283 & .005 \\
\hline
\end{tabular}

Hasil uji tabel 7 dan 8 memperlihaktan selisih antara nilai -2 Log Likelihood (-2LL) awal dengan nilai $-2 L L$ akhir yaitu sebesar $30,734(166,456-135,722)$. Nilai -2LL terjadi penurunan, membuktikan bahwa model regresi sudah semakin baik. Penurunan Log Likelihood (-2LL) menunjukkan model regresi logistic yang telah dihipotesiskan fit dengan data.

b. Uji Koefisien Determinasi (Nagelkerke R Square)

Tabel 9. Koefisien Determinasi (Nagelkerke $R$ Square)

\begin{tabular}{lccc}
\hline \multicolumn{4}{c}{ Model Summary } \\
\hline Step & -2 Log likelihood & Cox \& Snell R Square & Nagelkerke R Square \\
\hline 1 & $135.722^{\mathrm{a}}$ & .216 & .295 \\
\hline \multicolumn{4}{c}{ Sumber: Output SPSS, data diolah Juni 2020 }
\end{tabular}

Sumber: Output SPSS, data diolah Juni 2020

Sesuai hasil uji koefisien determinasi dalam tabel 9. membuktikan besar dari nilai Nagelkerke $R$ Square adalah 0,295 artinya variabilitas variabel independen sejumlah 29,5\% kemudian sebanyak 70,5\% diperjelas oleh variabel yang lain di luar dari model penelitian.

c. Uji Kelayakan Model Regresi dengan Hosmer and Lomeshow's Goodness of Fit Test

Tabel 10. Uji Hosmer and Lomeshow's

\begin{tabular}{cccc}
\hline \multicolumn{4}{c}{ Hosmer and Lemeshow Test } \\
\hline Step & Chi-square & Df & Sig. \\
\hline 1 & 4.274 & 8 & .832 \\
\hline \multicolumn{4}{c}{ Sumber: Output SPSS Versi } \\
\hline
\end{tabular}

Hasil uji Hosmer and Lemeshow's Goodness of Fit Test tabel 10. di atas membuktikan bahwa nilai Chi-Squre sebesar 4,274 dan tingkat signifikansinya (p) adalah 0,832>0,05 maka bisa diambil kesimpulan model sesuai dengan data penelitian atau model dapat memprediksi nilai observasi.

\section{d. Matriks Klasifikasi}

Tabel 11. Matriks Klasifikasi

\begin{tabular}{|c|c|c|c|c|c|}
\hline \multicolumn{6}{|c|}{ Classification Table ${ }^{\mathbf{a}}$} \\
\hline \multicolumn{3}{|c|}{ Observed } & \multicolumn{3}{|c|}{ Predicted } \\
\hline & & & \multicolumn{2}{|c|}{ Auditor Switching } & \multirow{2}{*}{$\begin{array}{c}\text { Percentage } \\
\text { Correct }\end{array}$} \\
\hline & & & $\begin{array}{c}\text { Mengganti } \\
\text { Auditor/KAP }\end{array}$ & $\begin{array}{l}\text { Tidak Mengganti } \\
\text { Auditor/ KAP }\end{array}$ & \\
\hline \multirow[t]{3}{*}{$\begin{array}{l}\text { Step } \\
1\end{array}$} & $\begin{array}{l}\text { Auditor } \\
\text { Switching }\end{array}$ & $\begin{array}{l}\text { Tidak Mengganti } \\
\text { Auditor/KAP }\end{array}$ & 57 & 22 & 72.2 \\
\hline & & $\begin{array}{l}\text { Mengganti } \\
\text { Auditor/KAP }\end{array}$ & 11 & 36 & 76.6 \\
\hline & Overall Pe & tage & & & 73.8 \\
\hline
\end{tabular}

Sumber: Output SPSS, diolah Juni 2020

Kekuatan prediksi model regresi menunjukkan sebanyak 47 perusahaan yang dapat diprediksi dan berpeluang dalam melakukan pergantian auditor (auditor switching), tetapi hasil observasi 
menunjukkan hanya 36 perusahaan, ketepatan klasifikasinya hanya mencapai 76,6\%. Hal itu membuktikan bahwa dengan mempergunakan model regresi maka hanya sebesar 36 perusahaan (76,6\%) dapat diprediksi mengganti auditor/KAP. Sedangkan kekuatan prediksi sebanyak 79 perusahaan menunjukkan tidak melakukan auditor switching, tetapi hasil observasi menunjukkan hanya ada 57 perusahaan, ketepatan klasifikasinya mencapai $72,2 \%$. Keseluruhan kekuatan untuk memprediksi dari model regresi pada penelitian ini adalah sejumlah $73,8 \%$.

\section{e. Uji Multikolinearitas}

Tabel 12. Uji Multikolinearitas

\begin{tabular}{llcrrr}
\hline \multicolumn{7}{c}{ Correlation Matrix } \\
\hline \multirow{3}{*}{ Step 1 } & \multicolumn{7}{c}{ Constant } & X1_OPA & X2_PMJ & X3_GROWTH \\
\cline { 2 - 6 } & Constant & 1.000 & -.696 & -.362 & -.169 \\
\cline { 2 - 6 } & X1_OPA & -.696 & 1.000 & .017 & .094 \\
\cline { 2 - 6 } & X2_PMJ & -.362 & .017 & 1.000 & .033 \\
\cline { 2 - 6 } & X3_GROWTH & -.169 & -.094 & .033 & 1.000 \\
\hline
\end{tabular}

Sumber: Output SPSS, diolah Juni 2020

Berdasarkan tabel 12. dilihat bahwa nilai korelasi semua variabel independen mempunyai nilai dibawah 0,95 atau 95\%, Sehingga bisa diambil kesimpulan tidak terjadi gejala multikolinearitas yang serius antar variabel opini audit(X1_OPA), pergantian manajemen(X2_PJM) dan pertumbuhan perusahaan(X3_GROWTH).

4. Uji Hipotesis Penelitian

a. Uji Wald Statistic (Uji Signifikansi Parsial)

Tabel 13. Uji Signifikansi Parsial

\begin{tabular}{|c|c|c|c|c|c|c|c|c|c|}
\hline \multicolumn{10}{|c|}{ Variables in the Equation } \\
\hline & & \multirow[t]{2}{*}{ B } & \multirow[t]{2}{*}{ S.E. } & \multirow[t]{2}{*}{ Wald } & \multirow[t]{2}{*}{ Df } & \multirow[t]{2}{*}{ Sig. } & \multirow{2}{*}{$\begin{array}{l}\text { Exp } \\
\text { (B) }\end{array}$} & \multicolumn{2}{|c|}{ 95\% C.I.for EXP(B) } \\
\hline & & & & & & & & Lower & Upper \\
\hline \multirow[t]{4}{*}{ Step $1^{\mathrm{a}}$} & X1_OPA & 2.077 & .430 & 23.298 & 1 & .000 & 7.978 & 3.433 & 18.539 \\
\hline & X2_PMJ & .283 & .483 & .342 & 1 & .559 & 1.327 & .515 & 3.421 \\
\hline & X3_GROWTH & .005 & .006 & .723 & 1 & .395 & 1.005 & .993 & 1.017 \\
\hline & Constant & -1.762 & .359 & 24.089 & 1 & .000 & .172 & & \\
\hline
\end{tabular}

Sumber: Output SPSS Versi-22, diolah Juni 2020

Merujuk hasil uji tabel 13. di atas, model dari persamaan regresi logistik pada penelitian ini dipaparkan berikut ini:

$$
\mathrm{Y}=(-1,762)+2,0770 \mathrm{PA}+0,283 \mathrm{PMJ}+0,005 \mathrm{GROWTH}+\mathrm{e}
$$

b. Uji Signifikansi Simultan (Omnibus Tests)

Tabel 14. Uji Signifikansi Model secara Simultan

\begin{tabular}{|c|c|c|c|c|}
\hline \multicolumn{5}{|c|}{ Omnibus Tests of Model Coefficients } \\
\hline & & Chi-square & Df & Sig. \\
\hline \multirow[t]{3}{*}{ Step 1} & Step & 30.734 & 3 & .000 \\
\hline & Block & 30.734 & 3 & .000 \\
\hline & Model & 30.734 & 3 & .000 \\
\hline
\end{tabular}

Sumber: Output SPSS, 2020

c. Moderated Regression Analysis (MRA)

Tabel 15. Uji Koefisien Determinasi $\left(R^{2}\right)$ Variabel $X, Y$ dan $Z$

\begin{tabular}{cccc}
\hline \multicolumn{3}{c}{ Model Summary } \\
\hline Step & -2 Log likelihood & Cox \& Snell R Square & Nagelkerke R Square \\
\hline 1 & $130.077^{\text {a }}$ & .251 & .342 \\
\hline
\end{tabular}

Sumber: Output SPSS, (2020)

Hasil uji koefisien determinasi di tabel 14. dieperoleh nilai Nagelkerke $R$ Square sebesar 0,342 . Nilai tersebut berarti variabel opini audit $\left(X_{1}\right)$, pergantian manajemen $\left(X_{2}\right)$, pertumbuhan perusahaan $\left(\mathrm{X}_{3}\right)$ dan financial distress $(\mathrm{Z})$ hanya mampu menjelaskan variabel auditor switching (Y) sebanyak 34,2\% dan sisanya dijelaskan oleh faktor lain diluar penelitian (tidak diteliti). Nilai koefisien determinasi Nagelkerke $R$ Square sebelum dimasukkannya variabel moderasi adalah sebesar 0,295 (29,5\%) dan setelah ada interkasi variabel moderasi, nilai $R$ Square menjadi 0,342 $(34,2 \%)$. Jadi kesimpulannya adalah variabel moderasi hanya bisa berkontribusi sebesar 0,047 $(4,7 \%)$ dalam menjelaskan variabel auditor switching. 
Tabel 16. Uji Interaksi (Moderated Regression Analysis)

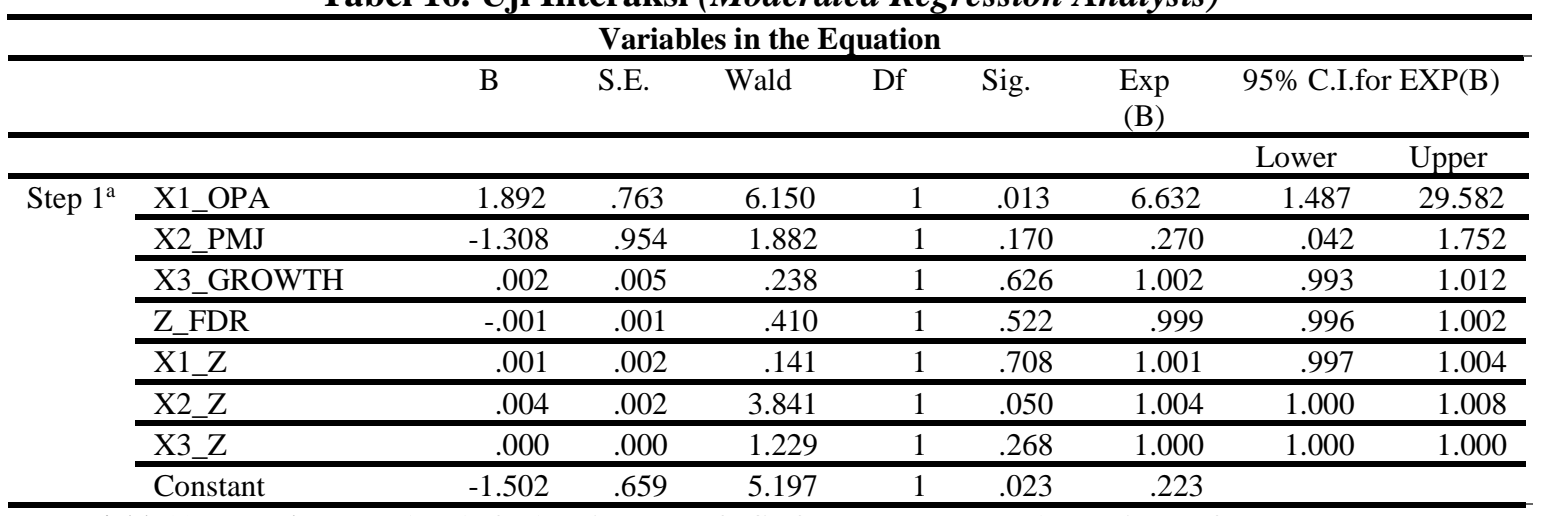

a. Variable(s) entered on step 1:X1_OPA, X2_PMJ, X3_GROWTH, Z_FDR, X1_Z, X2_Z, X3_Z.

Sumber: Output SPSS, (2020)

Sesuai tabel 16. di atas, dapat diketahui koefisien dalam persamaan model regresi dari penelitian ini yang akan disusun di dalam persamaan secara matematis sebagai berikut:

$$
\begin{gathered}
Y=-1,502+1,892 \text { OPA }-1,308 \text { PJM }+0,002 \text { GROWTH }+0,001 \text { OPA } * \text { FDR } \\
+0,004 \text { PJM } * \text { FDR }+0,00 \text { GROWTH } * \text { FDR }+e
\end{gathered}
$$

\section{Pembahasan Hasil Penelitian}

Sesuai dengan hasil uji sebelumnya maka pembahasan hasil penelitiannya sebagai berikut:

\section{a. Pengaruh Opini Audit terhadap Auditor Switching}

Tingkat probabilitas atau signifikansi $(\mathrm{p})$ dari variabel opini audit $\left(\mathrm{X}_{1}\right)$ menunjukkan nilai sebesar 0,00 lebih kecil dari $\alpha=0,05(0,00<0,05)$. Dapat diambil kesimpulan bahwa variabel opini audit $\left(\mathrm{X}_{1}\right)$ memiliki pengaruh positif signifikan terhadap variabel auditor switching $(\mathrm{Y})$ pada perusahaan sektor keuangan yang terdaftar di BEI tahun 2017-2019, artinya $\mathrm{H}_{1}$ diterima. Sehubungan dengan agency theory manajer perusahaan sebagai manusia memiliki sikap yang egois bertindak individual dengan mendahulukan kepentingan pribadi (Eisenhardt, 1989). Sehingga manajer merasa berhak untuk melakukan pergantian auditor jika audit opinion yang yang diterima tidak sesuai dengan keinginannya (manajer). Seorang auditor yang dituntut untuk melakukan kecurangan dalam pemberian audit opinion yang melanggar etika profesinya akan cenderung memutuskan kontrak audit dengan perusahaan sehingga hal ini juga dapat mengakibatkan terjadinya auditor switching. Hasil penelitian ini didukung dengan penelitian yang dilakukan oleh Alexandra et al., (2016); (Khasharmeh, 2015); Astria \& Wenny, (2018); Putra \& Suryanawa, (2016) dan Saputra, (2017).

\section{b. Pengaruh Pergantian Manajemen terhadap Auditor Switching}

Tingkat probabilitas atau signifikansi $(\mathrm{p})$ variabel pergantian manajemen $\left(\mathrm{X}_{2}\right)$ adalah sebesar 0,559 lebih besar dari $\alpha=0,05(0,559>0,05)$.Sehingga dinyatakan bahwa variabel pergantian manajemen $\left(\mathrm{X}_{2}\right)$ tidak memiliki pengaruh yang signifikan terhadap auditor switching $(\mathrm{Y})$ pada perusahaan sektor keuangan yang terdaftar di BEI tahun 2017-2019, $\mathrm{H}_{2}$ ditolak. Hasil dari penelitian membuktikan bahwa dengan pergantian manajemen atau CEO, tidak selalu menghasilkan perubahan kebijakan sehubungan dengan pergantian auditor/KAP. Hasil analisis menunjukkan ada beberapa perusahaan sektor keuangan yang memakai jasa KAP Big Four yang tidak dapat diragukan kualitas auditnya, sehingga perusahaan tidak melakukan auditor switching. Manajer mengemban tanggung jawab dalam mengembangkan perusahaan dan menyelenggarakan internal control secara efektif dalam perusahaan dan bertanggung jawab terhadap financial statement perusahaan. Sedangkan yang bertanggung jawab untuk menentukan auditor/KAP untuk melaksankan audit tahunan pada financial statement perusahaan merupakan tugas dari dewan komisaris (Mulyadi, 2014). Hasil penelitian ini tidak selaras dengan penelitian Saputra, (2017), tetapi sejalan dengan penelitian Dermawan, (2019) dan Karina et al., (2017).

\section{c. Pengaruh Pertumbuhan Perusahaan terhadap Auditor Switching}

Nilai signifikansi (p) Variabel pertumbuhan perusahaan $\left(X_{3}\right)$ menunjukkan sejumlah 0,395 > $\alpha=0,05$. Nilai tersebut membuktikan bahwa variabel pertumbuhan perusahaan $\left(\mathrm{X}_{3}\right)$ tidak bepengaruh terhadap auditor switching $(\mathrm{Y})$ pada perusahaan sektor keuangan yang terdaftar di Bursa Efek Indonesia, sehingga hipotesis ketiga $\left(\mathrm{H}_{3}\right)$ ditolak. Penelitian ini membuktikan bahwa pertumbuhan perusahaan tidak bisa menjamin perusahaan untuk melakukan auditor switching 
(pergantian akuntan publik/KAP). Hasil analisis data menunjukkan ada 22 perusahaan sektor keuangan yang mengalami pertumbuhan negatif. Pertumbuhan perusahaan negatif menyebabkan perusahaan tidak mampu melakukan auditor switching. Ketika pertumbuhan perusahaan negatif maka perusahaan tetap mempertahankan auditor/KAP, karena auditor dan KAP yang lama telah mengetahui keadaan perusahaan serta reputasi perusahaan akan tetap aman. Hasil dari penelitian ini sejalan dengan penelitian Maryani et al., (2017), Walidi, (2019) dan Karina et al., (2017).

\section{d. Pengaruh Opini Audit, Pergantian Manajemen dan Pertumbuhan Perusahaan} terhadap Auditor Switching

Hasil uji parsial dengan Omnibus Tests menunjukkan tingkat signifikasi/probabilitas (p) 0,00 $<0,05$ sehingga diambil kesimpulan variabel opini audit $\left(\mathrm{X}_{1}\right)$, pergantian manajemen $\left(\mathrm{X}_{2}\right)$ dan pertumbuhan perusahaan $\left(\mathrm{X}_{3}\right)$ secara simultan berpengaruh signifikan terhadap auditor switching (Y) pada perusahaan sektor keuangan yang terdaftar di BEI tahun 2017-2019, $\mathrm{H}_{4}$ diterima. Hasil penelitian ini membuktikan bahwa opini selain WTP yang diterima perusahaan dengan tingkat pertumbuhan perusahaan yang negatif membuat pemegang saham menilai bahwa kinerja dari seorang manajer buruk, yang akan menimbulkan pergantian manajer melalui RUPS. Opini dari auditor mencerminkan nilai dari perusahaan. Audit opinion sebelumnya dapat mempengaruhi nilai saham yang berpengaruh terhadap pertumbuhan perusahaan. Hal tersebut menyebabkan terjadinya auditor switching, karena manajer atau CEO yang baru untuk memilih KAP/Akuntan Publik yang mampu diajak kerja sama dan selaras dengan kebijakan serta pelaporan akuntansinya. Hasil peneltian ini sejalan dengan penelitian Faradila et al., (2016); Tami et al., (2019) dan Dermawan, (2019) yang merujuk hasil yang sama.

\section{e. Pengaruh Opini Audit terhadap Auditor Switching yang dimoderasi Financial Distress}

Hasil penelitian yang dilakukan dengan uji interaksi MRA, variabel korelasi antara variabel opini audit $\left(\mathrm{X}_{1}\right)$ dengan variabel financial distress $(\mathrm{Z})$, menunjukkan pengaruh tidak signifikan, karena nilai signifikansinya 0,708 >0,05 atau 5\%. Diambil kesimpulan bahwa interaksi antara opini audit dengan financial distress tidak memiliki pengaruh yang signifikan terhadap auditor switching dan dalam regresi ini bukan variabel moderating, yang artinya $\mathrm{H}_{5}$ ditolak. Penelitian ini membuktikan, bahwa walaupun perusahaan mendapatkan opini selain WTP bersamaan dengan kesulitan keuangan yang dihadapi, perusahaan akan memertahankan KAP/auditor yang lama. Manajemen membutuhkan auditor/KAP lama yang berpengalaman dan mengetahui kondisi perusahaan, untuk meminta saran perbaikan agar dapat keluar dari kondisi financial distress. Karena jika perusahaan mengganti auditor (auditor switching) akan membuat nilai perusahaan semakin turun dalam pandangan pihak eksternal perusahaan. Dengan melakukan pergantian Akuntan Publik ataupun KAP, belum tentu perusahaan akan menerima opini WTP (unqualified opinion), karena auditor yang baru akan melakukan evaluasi terhadap integritas manajemen perusahaan (klien) (mulyadi, 2014). Hasil penelitian ini sejalan dengan penelitian Putra \& Suryanawa, (2016) yang menunjukkan hasil yang sama, akan tetapi hasil penelitian ini tidak selaras dengan penelitian Astria \& Wenny, (2018).

\section{f. Pengaruh Pergantian Manajemen terhadap Auditor Switching yang dimoderasi Financial Distress}

Sesuai dengan hasil penelitian yang dilakukan melalui uji interaksi MRA, variabel interaksi antara pergantian manajemen $\left(\mathrm{X}_{2}\right)$ dengan financial distress $(\mathrm{Z})$ menghasilkan koefisien regresi positif sebesar 0,004 dan koefisien determinasi mengalami peningkatan positif 0,047, artinya financial distress $(\mathrm{Z})$ memperkuat pengaruh opini audit $\left(\mathrm{X}_{1}\right)$ dengan variabel auditor switching (Y). Sedangkan nilai signifikansi variabel interaksinya sebanyak $0,050 \leq 0,05$ atau 5\%. Dapat diambil kesimpulan interaksi antara variabel pergantian manajemen dan financial distress berpengaruh signifikan terhadap auditor switching pada perusahaan sektor keuangan yang terdaftar di BEI Tahun 2017-2019, dalam regresi ini merupakan variabel pemoderasi, sehingga $\mathrm{H}_{6}$ diterima. Hasil penelitian membuktikan bahwa, saat perusahaan menghadapi kesulitan keuangan atau financial distress tentunya shareholders akan menuntut diadakanya pergantian manajemen yang baru dalam RUPS, mereka menganggap manajer lama tidak dapat mengatasi financial distress yang mengakibatkan harga saham semakin menurun. Manajemen yang baru diharapkan dapat mengatasi terjadinya financial distress di dalam perusahaan. Dengan adanya manajemen atau CEO yang baru maka kebijakan dalam perusahaan juga akan berubah, seperti kebijakan akuntansi dan pemilihan KAP/Auditor yang sejajar dengan kebijakan manajemen baru. Ketidak 
puasan terhadap jasa yang telah diberikan oleh auditor/KAP yang lama membuat manajemer yang baru melakukan auditor switching. Hasil penelitian ini tidak sependaat dengan penelitian Nasir, (2018). Akan tetapi menunjukkan hasil yang sama dan sejalan dengan hasil penelitian Rosita, (2019).

\section{g. Pengaruh Pertumbuhan Perusahaan terhadap Auditor Switching yang dimoderasi Financial Distress}

Sesuai dengan hasil penelitian yang menggunakan uji interasi (MRA), variabel interaksi antara variabel pertumbuhan perusahaan $\left(\mathrm{X}_{3}\right)$ dengan financial distress $(\mathrm{Z})$, menunjukkan nilai signifikansi sebesar 0,268>0,05. Dapat diambil kesimpulan bahwa interaksi antara pertumbuhan perusahaan dengan financial distress tidak mempunyai pengaruh yang signifikan terhadap auditor switching dan dalam regresi ini bukan variabel pemoderasi, sehingga $\mathrm{H}_{7}$ diterima. Hasil penelitian ini membuktikan kesulitan keuangan (financial distress) yang dihadapi perusahaan dapat mengakibatkan menurunnya nilai pertumbuhan perusahaan, sehingga perusahaan tidak akan mengganti (mempertahankan) KAP/Auditornya yang lama. Perusahaan yang sedang menghadapi financial distress sulit dalam mencari Akuntan Publik ataupun KAP yang baru. Sebab KAP/Akuntan Publik cenderung menolak perikatan audit, apabila auditor memperoleh informasi bahwa calon kliennya sedang menderita kesulitan keuangan. Financial distress yang sedang dihadapi oleh calon kliennya (perusahaan) dapat menstimulasi manajemen dalam melakukan salah saji material pada laporan keuangannya untuk menyembunyiakan masalah keuangan atau financial distress (Mulyadi, 2014). Hasil dari penelitian ini selaras dengan penelitian yang dilaksanakan oleh Rosita, (2019).

\section{E. SIMPULAN DAN SARAN}

Berdasarkan hasil penelitian dan pembahasan yang dipaparkan sebelumnya maka dapat diambil kesimpulan sebagai berikut: (1) Opini audit memiliki pengaruh yang positif signifikan terhadap auditor switching, (2) Pergantian manejemen tidak berpengaruh signifikan terhadap auditor switching, (3) Pertumbuhan perusahaan tidak berpengaruh signifikan terhadap auditor switching, (4) Opini audit, pergantian manajemen dan pertumbuhan perusahaan secara simultan berpengaruh positif signifikan terhadap auditor switching, (5) Financial distress tidak dapat memoderasi pengaruh opini auditor terhadap auditor switching atau dengan kata lain financial distress bukan termasuk variabel moderasi, (6) Financial distress mampu memoderasi pengaruh pergantian manajemen terhadap auditor switching, (7)Financial distress tidak mampu memoderasi pengaruh pertumbuhan perusahaan terhadap auditor switching atau dengan kata lain financial distress bukan termasuk variabel moderasi pada perusahaan sector keuangan yang terdaftar di Bursa Efek Indonesia Tahun 2017-2019.

Berdasarkan hasil penelitian dan keterbatasan penelitian maka saran yang diberikan peneliti antara lain yaitu: (1) Bagi peneliti selanjutnya disarankan untuk memperluas sampel penelitian dengan mempertimbangkan penggunaan seluruh perusahaan yang terdaftar di BEI. (2) Bagi profesi Akuntan Publik (auditor eksternal) diharapkan agar dapat menjaga independensinya dalam melakukan jasa audit dan memberikan opini atau pendapat atas laporan keuangan perusahaan dengan baik sehingga menghasilkan laporan audit yang andal dan relevan. (3) Bagi perusahaan sektor keuangan diharapkan agar menghindari praktik yang tidak sehat. (4) Bagi stakeholders perusahaan diharapkan lebih cermat dalam melakukan investasi ataupun memberikan pinjaman pada perusahaan.

\section{DAFTAR RUJUKAN}

Abdul Nasser, A. T., Abdul Wahid, E., Mustapha Nazri, S. N. F. S., \& Hudaib, M. (2006). "Auditor-client relationship: The case of audit tenure and auditor switching in Malaysia." Managerial Auditing Journal, 21(7), 724-737. https://doi.org/10.1108/02686900610680512

Alexandra, P., Alegria, F., \& Mouta, M. (2016). "The change of auditor: The Portuguese case." Cómo Citar Este Artículo:, 19(2), 181-186. https://doi.org/10.1016/j.rcsar.2015.05.001

Aprillia, E. (2013). Pengaruh Pergantian Manajemen , Ukuran KAP Terhadap Auditor Switching ( Studi Kasus pada Perusahaan Perbankan yang Terdaftar di Bursa Efek Indonesia Tahun 2008-2011). Universitas Negeri Semarang. 
Arezoo Aghaei Chadegani, Z. M. M. \& A. J. (2011). "The Determinant Factors of Auditor Switch among Companies Listed on Tehran Stock Exchange." International Research Journal of Finance and Economics, 80, 158-167. http://www.internationalresearchjournaloffinanceandeconomics.com

Astria, D., \& Wenny, C. D. (2018). "Pengaruh Opini Audit dan Ukuran Perusahaan Pada Auditor Switching dengan Financial Distress Sebagai Variabel Moderasi.” x, 1-16.

Budisantoso, T., Rahmawati, R., Bandi, B., \& Probohudono, A. N. (2017). "Determinant of Downward Auditor Switching." Jurnal Akuntansi Multiparadigma, 8(3), 444-457. https://doi.org/10.18202/jamal.2017.12.7065

Calderon, T. G. and E. O. (2008). "Determinants of Client-initiated and Auditor-initiated Auditor Changes." Managerial Auditing Journal, 24-32(23 (1)).

Cameran, Mara, Annalisa Prencipe, \& M. T. (2009). "Does Mondatory Audit Firm Rotation Really Improve Audit Quality." Annual Meeting New York, 1-10.

Carcello, J.V., \& T. L. N. (2003). "Audit Committee Characteristics and Auditor Dismissals following New Going Concern Reports." The Accounting Review, 95-105(78(1)).

Cooke, M. H. \& T. E. (2005). The Impact of Managing Director Changes and Financial Distress on Audit The Impact of Managing Director Changes and Financial Distress on Audit Qualification and Auditor Switching. Journal of Business Finance \& Accounting, 32(9), 1703-1736. https://doi.org/10.1111/j.0306-686X.2005.00645.x

Dermawan, A. (2019). "Analisis Faktor-Faktor Yang Mempengaruhi Auditor Switching" [Universitas Sumatera Utara]. http://eprints.ums.ac.id/id/eprint/51689

Eisenhardt, K. M. (1989). "Agency Theory: An Assessment and Review." Academy of Management Review, 14(1), 57-74.

Faradila, Y., Yahya, M. R., Akuntansi, P. S., \& Kuala, U. S. (2016). "Pengaruh Opini Audit , Financial Distress dan Pertumbuhan Perusahaan Klien Terhadap Auditor Switching." Jurnal Ilmiah Mahasiswa Ekonomi Akuntansi (JIMEKA), 1(1), 81-100.

Ghozali, I. (2013). "Aplikasi Analisis Multivariat dengan Program IBM SPSS 21” (Edisi 7). Penerbit Universitas Diponegoro.

Hery. (2016). Auditing dan Assurans. Grasindo.

Holowczak, R., Louton, D., \& Saraoglu, H. (2019). "Testing market response to auditor change filings : A comparison of machine learning classifiers." The Journal of Finance and Data Science, 5(1), 48-59. https://doi.org/10.1016/j.jfds.2018.08.001

Jogiyanto. (2010). "Teori Portofolio dan Analisis Investasi" (Tujuh). BPFE-Yogyakarta.

Karina, F. L., Kholmi, M., \& Harventy, G. (2017). "Pengaruh Opini Going Concern, Pergantian Manajemen Dan Ekspansi Internal Terhadap auditor Switching Secara Voluntary." Jurnal Reviu Akuntansi Dan Keuangan, 4(1), 555-562. https://doi.org/10.22219/jrak.v4i1.4928

Katadata.co.id. (2019). "Kronologi Kemelut Jiwasraya dari Masa Pemerintahan SBY hingga Jokowi." $\quad$ https://katadata.co.id/berita/2019/12/22/kronologi-kemelut-jiwasraya-darimasa-sby-hingga-jokowi

Khasharmeh, H. A. (2015). "Determinants Of Auditor Switching In Bahraini's Listed Companies An Empirical Study." European Journal of Accounting, Auditing and Finance Research, 3(11), 73-99.

Liputan6.com. (2014). "Enron, Skandal Besar Perusahaan Energi yang Cekik Investor." https://www.liputan6.com/bisnis/read/2031867/enron-skandal-besar-perusahaan-energiyang-cekik-investor

Manto, J. I., \& Lesmana Wanda, D. (2018). "Pengaruh Financial Distress, Pergantian Manajemen dan Ukuran KAP Terhadap Auditor Switching." Media Riset Akuntansi, Auditing \& Informasi, 18(2), 205. https://doi.org/10.25105/mraai.v18i2.3212

Maryani, S., Respati, N. W., \& Safrida, L. (2017). "Pengaruh Financial Distress, Pertumbuhan Perusahaan, Rentabilitas, Ukuran KAP dan Ukuran Perusahaan Terhadap Pergantian Auditor." Jurnal Reviu Akuntansi Dan Keuangan, 6(2), 873-884. https://doi.org/10.22219/jrak.v6i2.04

Meckling, M. c. J. and W. H. (1976). "Theory of The Firm : Managerial Behavior, Agency Costs And Ownership Structure I ". Journal of Financial Economics, 3, 305-360.

Mohammad Bagherpour, G. S. M. and G. S. (2010). Auditor Switching in an Increasingly 
Competitive Audit Market. Working Papers, 1-31.

Mulyadi. (2014). Auditing Buku 1 (Edisi 6). Salemba Empat.

Nasir, A. (2018). "Pengaruh Opini Audit, Pergantian Manajemen dan Fee Audit Terhadap Auditor Switching dengan Financial Distress Variabel Moderasi”. JOM FEB, 1(1), 1-15.

Nazri, S. N. F. S. M., Smith, M., \& Ismail, Z. (2012). Factors influencing auditor change: evidence from Malaysia. Asian Review of Accounting.

Peraturan Pemerintah Nomor 20 Tahun 2015 tentang "Praktik Akuntan Publik."

Pradana Pinto, T. (2016). Kemampuan Pertumbuhan Perusahaan Memoderasi Pengaruh Financial Distress Terhadap Auditor Switching. E-Jurnal Akuntansi, 15(1), 727-753.

Praptika, P., \& Rasmini, N. (2016). "Pengaruh Audit Tenure, Pergantian Auditor dan Financial Distress pada Audit Delay." E-Jurnal Akuntansi, 15(3), 2052-2081.

Primbardi, R. B. (2014). Determinan Auditor Switching Pada Perusahaan Non Keuangan. Universitas Diponegoro.

Putra, I., \& Suryanawa, I. (2016). "Pengaruh Opini Audit dan Reputasi KAP Pada Auditor Switching dengan Financial Distress Sebagai Variabel Moderasi." E-Jurnal Akuntansi, 14(2), 1120-1149.

Riduwan, C. S. dan A. (2015). "Faktor - Faktor yang Memengaruhi Perusahaan Melakukan Pergantian Auditor". Jurnal Ilmu \& Riset Akuntansi.

Rosita, S. (2019). "Faktor-Faktor yang berpengaruh Terhadap Auditor Switching dengan Financial Distress Sebagai Variabel Moderasi.” Accounting Analysis Journal, 4(672013167), 0-18.

Safriliana, R., \& Muawanah, S. (2019). "Faktor yang Memengaruhi Auditor Switching di Indonesia." Jurnal Akuntansi Aktual, 5(3), 234-240. https://doi.org/10.17977/um004v5i32019p234

Salleh, K., \& Jasmani, H. (2014). "Audit rotation and audit report: empirical evidence from Malaysian PLCs over the period of ten years." Procedia - Social and Behavioral Sciences, 145, 40-50. https://doi.org/10.1016/j.sbspro.2014.06.009

Saputra, G. (2017). "Pengaruh Opini Going Concern dan Pergantian Manajemen Terhadap Auditor Switching, Reputasi Auditor Sebagai Variabel Moderating." JOM Fekon, 4(1), 32563268.

Saputri, I. I. (2018). Pengaruh Opini Audit, Ukuran Kap, Pergantian Manajemen, Financial Distress, Dan Profitabilitas Perusahaan Terhadap Auditor Switching.

Svanberg, J. dan P. O. (2015). "Lost Revenues Associated with Going Concern Modified Opinions in the Swedish Audit Market." Journal of Applied Accounting Research, 15(2), 197-214.

Syofyan, F. Z. dan E. (2019). "Pengaruh Financial Distress, Pertumbuhan Perusahaan Klien, Ukuran KAP, dan Audit Delay Terhadap Auditor Switching." Jurnal Eksplorasi Akuntansi, 1 (3)(Seri F), 1556-1568. http://jea.ppj.unp.ac.id/index.php/jea/issue/view/13

Tami Rezki Pratiwi Sudrajad, D. P. dan E. S. (2019). "Faktor-Faktor yang Mempengaruhi Auditor Switching." E-Proceeding of Management, 6(1), 600-613.

Ulya, H. (2019). Pengaruh Pertumbuhan Perusahaan, Pergantian Manajemen, Opini Audit, Financial Distress dan Ukuran KAP Terhadap Auditor Switching. Universitas Muhammadiyah Surakarta.

Walidi, R. R. B. M. dan S. (2019). "Pengaruh Ukuran Perusahaan, Pertumbuhan Perusahaan dan Ukuran KAP Terhadap Auditor Switching." Jurnal Akrab Juara, 6(1), 196-209. https://doi.org/10.1109/MTAS.2004.1371634

Weston, J. F. dan T. E. C. (1997). Manajemen Keuangan (edisi 9). Binarupa Aksara.

Yudha, P., Putri, A., Bagus, I., \& Astika, P. (2017). "Kemampuan Pergantian Auditor dan Prior Opinion Memoderasi Pengaruh Potensi Financial Distress Terhadap Opini Going Concern." E-Jurnal Ekonomi Dan Bisnis Universitas Udayana, 9(6), 3259-3284.

Yusriwarti. (2019). Pengaruh Opini Audit, Financial Distress dan Ukuran Perusahaan Terhadap Auditor Switching pada Perusahaan Manufaktur yang terdaftar di BEI. Jurnal Akuntansi Dan Keuangan, 8(1), 94-109.

www.idx.co.id 